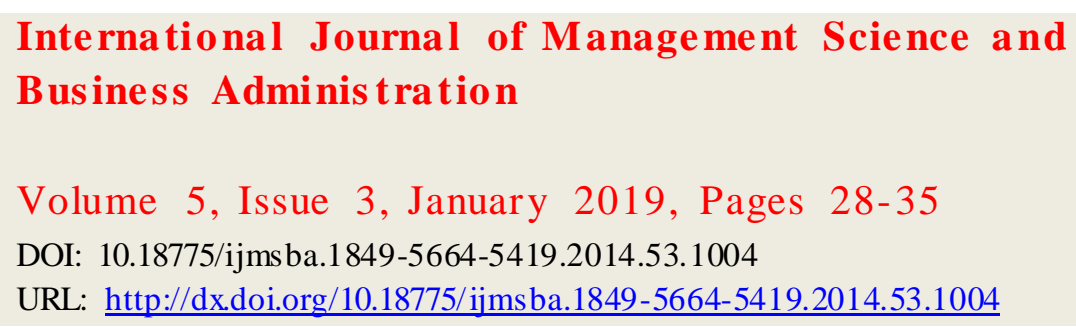

\title{
Towards MSE Technology Adoption Model for Business Growth in Kenya
}

\section{Peter Kithae \\ Management University of Africa, Nairobi, Kenya}

\begin{abstract}
Technology has been described as "the systematic application of scientific and other organized knowledge to practical task". This study focused on youth-led MSES located in Makueni district of Kenya. A descriptive research design was used to carry out the study. Stratified random sampling technique was employed to select a sample of 119 out of the target population of 396. A three-part questionnaire consisting of both quantitative and qualitative questions was the main instrument for collecting data. Both quantitative and qualitative data was collected to reveal the strengths and show the main themes. Quantitative data were analyzed using the SPSS software. From the study, it was revealed that most youths had adopted technology in the form of training and purchase of equipment and that very few experienced and well-established entrepreneurs were able to sub-contract and /or franchise. It was also revealed that technology adopted had impacted positively on the youth-led MSEs in that it has improved quality of goods produced; increased productivity of the enterprise; improved marketability of business products and thus steady growth and enhanced business competitiveness in the market. The MSE technology adoption model developed from the study suggested that a deliberate action aimed at enhancing technology adoption amongst MSEs need to be taken possibly through injection of more capital, provision of emerging quality improvement techniques and creation of MSE linkages and networks among o thers.
\end{abstract}

Keywords: Technology, Micro and small enterprises, Technology adoption model

\section{Introduction and Research Objectives}

Technology has been described as "the systematic application of scientific and other organized knowledge to practical task". When applied to micro and small enterprises, technology has proved to be the engine of economic growth amongst "Asian Tigers". The purpose of technology is to improve the productivity of enterprises and enhance the quality of goods produced by enterprises to help them withstand local and international competition. (ILO/UNDP, 2000).In a market oriented environment, one way of achieving and maintaining competitiveness is by creating knowledge faster than competitors (Albu, 1997: Maskell and Malmberg, 1999). In turn, this depends on cost advantages, innovation and the continuous improvement of products and services - all coming through the capability to generate and manage technical change (Moyi and Njiraini. 2005).

\subsection{Statement of the Problem}

According to Haan (1999), there is evidence that SMEs in Kenya are continually engaged in adapting Industrial equipment for their use and self-constructing tools and equipment. There is also evidence that other informal sources of information such as friends and mere imitation through observations are common (Ngahu, 1995; Haan, 1999). Coupled with this, the government of Kenya has done the following to empower micro and small enterprises. First, the government has issued new regulations on tendering so that all government agencies will be compelled to give preferential treatment to bids for MSES.

Secondly, the government has encouraged technical Institutes and other relevant bodies to develop simple goods and production methods. Thirdly, the government has been disseminating information on new products and production methods to potential producers. Fourthly, the government has revised building codes to favor architectural and engineering structures that make intensive use of products supplied by MSEs; and, lastly, the governme nt has encouraged the formation of co-operatives as a means through which MSEs would access information and support on technology, 
credit, input and markets (Moya and Njiraini, 2005).

However, despite all this, the baseline survey of 1999 estimated that $80 \%$ of the MSEs fail within their first three years due to problems related to appropriate technology (GOK, 2001). This research study aimed at finding reasons for this to bridge the existing gap. It was to reveal technology adoption forms applied and their effect on the performance of MSEs. Specifically, the study was to investigate if there is any relationship between technologies that micro and small entrepreneurs have and the performance of their enterprises. Once completed, the study aimed at empowering MSEs to be on the roadway to the achievement of Kenya's vision 2030.

\subsection{Statement of the Problem}

The overall objective of this study was to find out if there is any relationship between technologies that micro and small entrepreneurs have and the performance of their enterprises.

\subsection{Research Questions}

The study aimed at finding answers to the following research questions

i. How much does technology affect the MSE's product and service quality?

ii. To what extent does technology affect MSE's productivity?

\subsection{Research Questions}

The findings will be of great assistance to donors as they will be able to engage suitable technology transfer mechanis ms and implementers. It will also give direction on prioritizing the expenditure of the donors and policymakers in consideration to areas where the strategies should be focused so as to promote MSE's development effectively and lead them towards the achievement of Kenya's vision 2030.

\subsection{Definition of Terms}

The study used keywords under the following operational definitions.

\subsection{Micro and Small Enterprises (MSEs)}

Micro or small enterprise is an undertaking, which employs between 1 and 20 employees, with capital investment of not more than kshs 30 million. Operational and administrative management lies in the hands of one to three persons who usually make a significant decision.

\subsection{Technology Adoption}

Is the modification of existing technology to meet the needs of specific types of producers or consumers, become compatible with locally available materials or local tastes and preferences or take advantage of a relative abundance of labor relative to capital.

\section{Theoretical Background and Informing Literature Review Background}

At the onset of the industrial revolution came in technological innovations. Today, this has become the scene of information explosion. The world has shrunk in size to a global village. Quality has become the buzzword for survival (Oakland, 1999). Micro and small enterprises have to cope up to the challenges of operating in a very dynamic, technological, competitive and volatile environment. It is only those firms that will embrace quality as their core business which will survive the onslaught that competition brings with it.

There are many new market entrants with 'bigger stick' which will give existing firms a good run for their money. Successfulbusiness operation depends on the ability to compete; the ability to compete depends largely on the quality of the product (Lyman \& Grubellini, 1975). This will, therefore require that an entrepreneurial organization work towards product/service improvement continuously. This will, in turn, call for managerial talent that is capable of harnessing organizational resources - human, material, physical and informational resources-efficiently and effectively toward meeting the organization's objectives and goals. Most organizations' objectives are to make profits; which is partly realized through the provision of competitive and quality products/services. 


\subsection{Conceptual Framework}

The paper conceptualizes that training, purchase of equipment, franchising and sub-contracting (technology adoption forms) are closely related to MSE performance (dependent variable) and that their effects were expected to impact positively on the performance of MSEs as shown in figure 3.1 below.

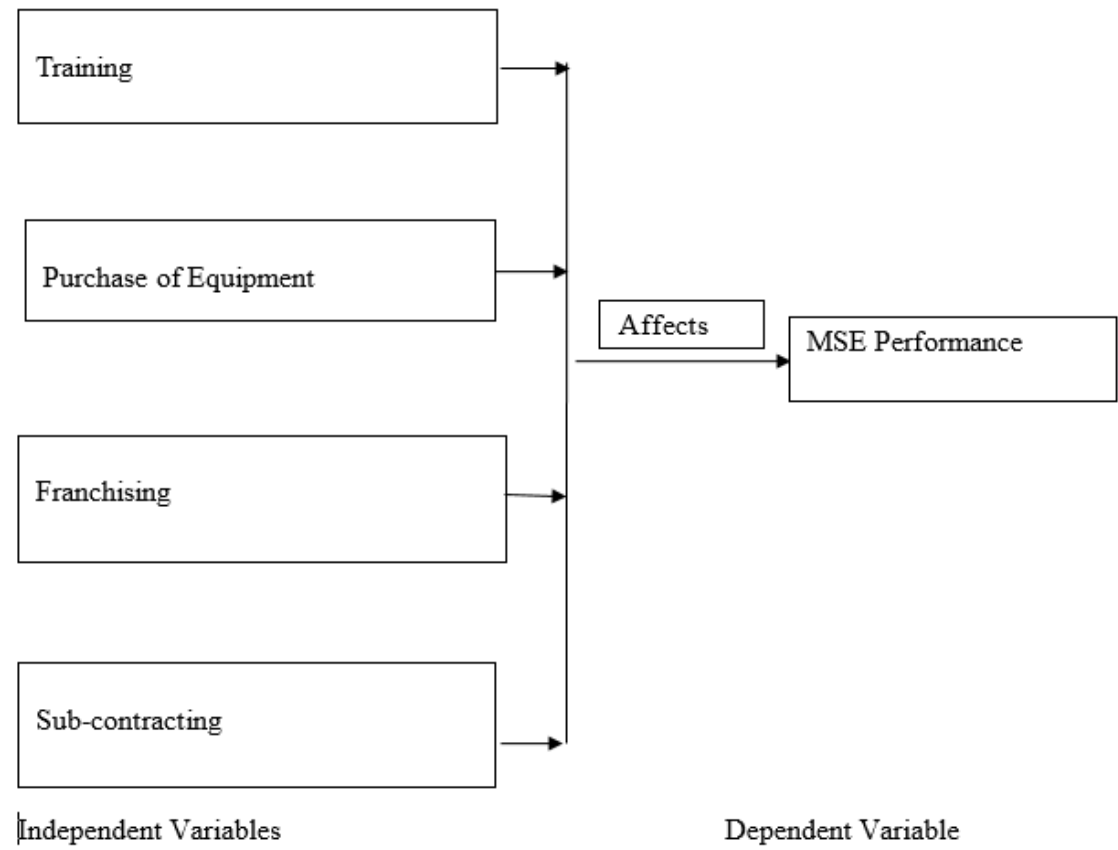

Figure1: Conceptual framework

\section{Components of MSE Performance (dependent variable) in the above figure may be explained as follows}

Performance of Micro and Small Enterprises takes the form of improvement in the quality of products and services rendered, marketability of the products, increase in quantity of goods produced, improved efficiency of operations, sustainability and growth prospects and hence increased the competitiveness of the firm. There is a growing realization that high-quality goods and services can give an organization a considerable competitive edge over its competitors. Good quality reduces the cost of rework, scrap, and returns and, most importantly, generate satisfied customers.

Firms are able to assimilate and adopt technology by developing technical capabilities which are the information and skills (technical, managerial and Institutional) that allow productive enterprises to utilize equipment and technology efficiently (Gichira, 1999). However, studies undertaken in African countries reveal a weak learning environment which is attributed to lack of import and export competition. Biggs et al (1995) suggests that the most important investment in new technology that MSEs in Africa can adopt is importation of new technology in the form of franchising, subcontracting and licensing. He further concurs with Gichira (1999) that firm size and firm age are the major determinants of investment in training and technology; with old and large firms investing more. The two papers conclude that the accumulation of human capital increases the firm's productivity through worker training and investment in technology .

\subsection{Research Gap}

From the above, it is clear that small enterprise sector is recognized as having potential to enhance job creation through the establishment of industries and initiation of commercial enterprises (GOK, 2001). It is also clear that much has been done to promote programmes aimed at improving the Kenyan economy through promotion of SMES (GOK, 1992; GOK, 1997 and GOK, 1999).

Skills upgrading not only enhances employee technical and managerial skills but also increases MSE's ability to adopt new technologies. When incorporated in the introduction of new technology, skills upgrading has been shown to have a crucial impact on productivity as it involves experimentation, modification and adaptation to the enterprises (Enos, 1992; Awe and Tan, 1995). 


\section{Research Methodology}

The study used both qualitative and quantitative research designs reveal the direction and strengths of the variables while at the same time show the main themes. The design was descriptive; as Gall and Borg (1989) noted, "Descriptive studies by nature emphasis interpretation".

The target population for this study was Micro and Small Enterprises in Embu district who received any form of technology between 2008 and 2010. Stratified random sampling technique was used to get a study sample of 60 MSEs as it gives all target population within a stratum an equal chance of being selected. Qualitative data were manually analyzed using the researcher's insight and research skills to bring out the main themes and were then operationalized for content analysis and to make meanings and importance of the study. On the other hand, responses to quantitative questions were electronically analyzed to reveal the relationship between the dependent and independent variables.

\section{Research Findings and Discussions}

This chapter examined the research objectives formulated in relation to the findings obtained. Conclusions and recommendations were subsequently given are based on information generated from the analysis of the questionnaire.

The overall data on the business profile indicates that most entrepreneurs have a sole proprietorship form of business of three to four years of operation. These businesses are in the service industry and the major investment in technology amongst most businesses is training.

\subsection{Business Major Investment in Technology}

The study revealed that $54 \%$ of all businesses had training as their major investment in technology, $28 \%$ in equipment, $16 \%$ in the franchise and only $2 \%$ on others. These results imply that major investment in technology amongst mses is training. These findings tend to strengthen Ikiara's and UNIDO's as sertion that education and on job training are drivers of adoption, survival and growth amongst enterprises and economies (Ikiara et al, 2005; UNIDO, 2004). Likewise, the results also compare reasonably well with Biggs et al (1995) and Gichira (1999) that firms in Africa have not invested much since they are young and small and that most of their investment in technology is in training. This means that these businesses are not able to reap much from emerging technologies as they have invested in only one form, training. Figure 2 below shows entrepreneurs' major invest.

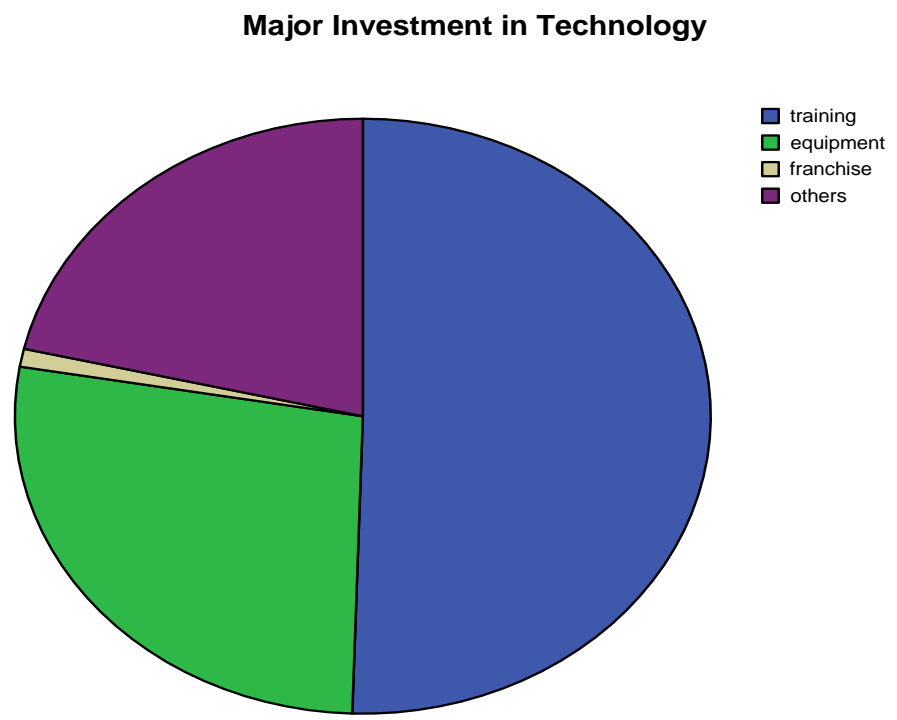

Figure 2: Pie chart showing major investment in technology and their frequencies

Answers to research questions were summarized as follows: 
How much does technology affect MSE's product and service quality?

Most respondents perceived that technology is of much help in improving quality as well as increasing sales volume of the products. However, there is a minimal correlation between technology in use and MSEs performance. Major challenges experienced are insufficient finances and irrelevant skills.

To what extent does technology affect MSE's productivity?

Most entrepreneurs felt that technology is of much help in improving their MSE productivity. However, a few of them did not feel its effect. Pearson's correlation matrix shows a very low correlation between technology and MSE performance. Major challenge in using the technology include inefficient machines and an important intervention measure suggested to enhance effectiveness in the technology is the provision of finances, training and provision of efficient machines.

\subsection{Pearson's Correlations Matrix}

When independent variables are plotted against the dependent variable on a Pearson's correlation matrix, they indicate how the two variables are related to each other through a combined mean correlation coefficient. A correlation coefficient of +1.00 implies that the variables are positively correlated; a situation which in our case would imply that technology is being adopted by entrepreneurs and is very well enhancing the MSEs performance and thus giving them a competitive advantage in the market. A correlation coefficient of -1.00 , on the other hand, would imply that the variables are negatively correlated and in our case, it would imply that technology is hindering MSEs from performing and thus rendering them weak in their competitiveness.

\subsection{The study Results}

\subsubsection{Personal and Business Details on MSE Performance Indicators}

When personal and business details (independent variables) are plotted against MSE performance indicators (dependent variable), the results give very low correlation coefficients. These coefficients indicate very weak correlations and imply that age, marital status, professional as well as academic qualification, business legal form, years of operation and business activity all do not influence MSE performance.

\subsubsection{Major Investment in Technology on MSE Performance Indicators}

When personal and business details (independent variables) are plotted against MSE performance indicators (dependent variable), the results give very low correlation coefficients. These coefficients indicate very weak correlations and imply that age, marital status, professional as well as academic qualification, business legal form, years of operation and business activity all do not influence MSE performance.

Table 1: Pearson's Correlations matrix- Effect of personal and business details on the performance of MSEs

\begin{tabular}{|c|c|c|c|c|c|c|c|c|c|c|}
\hline $\begin{array}{l}\text { INDEPEND } \\
\text { VARIABLE } \\
\text { DEPEN } \\
\text { VARIABLE }\end{array}$ & Age & $\begin{array}{l}\text { Marital } \\
\text { status }\end{array}$ & $\begin{array}{l}\text { Number } \\
\text { of } \\
\text { Children }\end{array}$ & $\begin{array}{l}\text { Academic } \\
\text { Qualificatio } \\
\mathrm{n}\end{array}$ & $\begin{array}{l}\text { Profession } \\
\text { al } \\
\text { qualificatio } \\
n\end{array}$ & $\begin{array}{l}\text { Work } \\
\text { Experience } \\
\text { (yrs) }\end{array}$ & $\begin{array}{l}\text { Legal } \\
\text { Form }\end{array}$ & $\begin{array}{l}\text { Years } \\
\text { of } \\
\text { operatio } \\
n\end{array}$ & $\begin{array}{l}\text { Busines } \\
\text { s } \\
\text { Activity }\end{array}$ & $\begin{array}{l}\text { Major } \\
\text { Invest in } \\
\text { Technol } \\
\text { ogy }\end{array}$ \\
\hline Age & 1 & $.453\left({ }^{\star \star}\right)$ & $\left..311^{* *}\right)$ & $.242\left(^{*}\right)$ & $.196\left(^{*}\right)$ & $.516\left(^{* *}\right)$ & -.123 & $\left..305^{(*}\right)$ & .072 & .045 \\
\hline Marital status & $\left..453^{(* *}\right)$ & 1 & $.454\left(^{\star \star}\right)$ & .125 & .110 & $\left..448^{(* *}\right)$ & -.021 & $.402\left(^{* *}\right)$ & $.202\left(^{\star}\right)$ & .057. \\
\hline $\begin{array}{l}\text { Number } \\
\text { of Children }\end{array}$ & $.311\left(^{* \star}\right)$ & $.454\left({ }^{\star \star}\right)$ & 1 & .133 & .150 & $.259\left({ }^{* *}\right)$ & .001 & .141 & .101 & .001 \\
\hline $\begin{array}{l}\text { Academic } \\
\text { Qualification }\end{array}$ & $.242\left(^{*}\right)$ & .125 & .133 & 1 & $.339\left(^{\star \star}\right)$ & .193 & -.071 & .137 & $.270\left(^{\star \star}\right)$ & $.207\left(^{*}\right)$ \\
\hline $\begin{array}{l}\text { Professional } \\
\text { qualification }\end{array}$ & $.196\left(^{*}\right)$ & .110 & .150 & $.339\left(^{\star \star}\right)$ & 1 & $.250\left(^{\star}\right)$ & -.027 & $.228\left(^{*}\right)$ & .067 & .038 \\
\hline $\begin{array}{l}\text { Work } \\
\text { Experience }\end{array}$ & $.516\left({ }^{\star \star}\right)$ & $.448\left({ }^{* \star}\right)$ & $.259\left(^{\star \star}\right)$ & .193 & $.250\left(^{\star}\right)$ & 1 & $\begin{array}{l}- \\
.211\left(^{*}\right)\end{array}$ & $.718\left(^{* *}\right)$ & $.252\left(^{\star}\right)$ & .088 \\
\hline Legal Form & -.123 & -.021 & .001 & -.071 & -.027 & $-.211\left(^{*}\right)$ & 1 & $-.199\left(^{*}\right)$ & .150 & .013 \\
\hline $\begin{array}{l}\text { Years of } \\
\text { operation }\end{array}$ & $\left..305^{(*}\right)$ & $.402\left({ }^{* *}\right)$ & .141 & .137 & $.228\left(^{*}\right)$ & $.718\left(^{* *}\right)$ & $\begin{array}{l}- \\
.199\left(^{*}\right)\end{array}$ & 1 & .137 & .034 \\
\hline $\begin{array}{l}\text { Business } \\
\text { Activity }\end{array}$ & .072 & $.202\left(^{\star}\right)$ & .101 & $.270\left(^{\star \star}\right)$ & .067 & $.252\left(^{\star}\right)$ & .150 & .137 & 1 & $.337\left(^{* *}\right)$ \\
\hline $\begin{array}{l}\text { Major Invest } \\
\text { Technology }\end{array}$ & .045 & .057 & .001 & $.207\left(^{\star}\right)$ & .038 & .088 & .013 & .034 & $.337\left(^{\star \star}\right)$ & 1 \\
\hline
\end{tabular}


Peter Kithae

Towards MSE Technology Adoption Model for Business Growth in Kenya

\begin{tabular}{|c|c|c|c|c|c|c|c|c|c|c|}
\hline $\begin{array}{l}\text { Faster } \\
\text { Production }\end{array}$ & -.005 & -.124 & $-.219\left(^{*}\right)$ & .023 & .014 & .017 & -.090 & .022 & .184 & -.128 \\
\hline $\begin{array}{l}\text { Saving on } \\
\text { Labour Cost }\end{array}$ & .037 & $-.251\left(^{*}\right)$ & -.180 & -.046 & -.126 & -.093 & -.095 & -.110 & .036 & -.030 \\
\hline $\begin{array}{l}\text { Saving on } \\
\text { Time }\end{array}$ & .070 & -.163 & -.111 & -.072 & $.235\left(^{*}\right)$ & .058 & -.094 & .045 & -.008 & .002 \\
\hline $\begin{array}{l}\text { Substitute for } \\
\text { Cheaper } \\
\text { Material } \\
\text { Increase }\end{array}$ & .006 & -.088 & -.163 & .186 & .090 & -.085 & -.046 & .056 & .130 & $.387\left(^{\star *}\right)$ \\
\hline $\begin{array}{l}\text { Production } \\
\text { Efficiency }\end{array}$ & .056 & -.160 & -.022 & .143 & .093 & -.019 & .050 & -.077 & $.194\left(^{*}\right)$ & .106 \\
\hline $\begin{array}{l}\text { Reduced } \\
\text { Operation } \\
\text { Costs }\end{array}$ & $.205\left(^{\star}\right)$ & .015 & -.144 & .080 & .018 & .092 & -.158 & .032 & $.223\left(^{*}\right)$ & $.382\left({ }^{* \star}\right)$ \\
\hline $\begin{array}{l}\text { Reduced } \\
\text { w orking } \\
\text { Capital Req. } \\
\text { Improving }\end{array}$ & .102 & .051 & $-.201\left(^{*}\right)$ & -.018 & .079 & .039 & -.042 & .101 & .127 & $.277\left({ }^{* *}\right)$ \\
\hline $\begin{array}{l}\text { Product } \\
\text { Reliability }\end{array}$ & .162 & .050 & .165 & .040 & -.072 & .043 & .088 & -.057 & .045 & .125 \\
\hline $\begin{array}{l}\text { Better } \\
\text { Packaging } \\
\text { Greater Self }\end{array}$ & -.108 & -.014 & -.006 & -.029 & -.015 & -.045 & -.102 & -.143 & -.128 & -.034 \\
\hline $\begin{array}{l}\text { Sufficiency in } \\
\text { supplies } \\
\text { Increased }\end{array}$ & $-.260\left(^{* \star}\right)$ & $-.276\left({ }^{* \star}\right)$ & -.076 & -.024 & .027 & $-.272\left({ }^{\star \star}\right)$ & -.049 & -.038 & -.096 & .108 \\
\hline $\begin{array}{l}\text { Market } \\
\text { Independenc } \\
\text { y }\end{array}$ & $.232\left(^{\star}\right)$ & -.135 & -.090 & .146 & .110 & .055 & -.170 & -.023 & -.042 & $.267\left(^{\star \star}\right)$ \\
\hline $\begin{array}{l}\text { Development } \\
\text { of Skills }\end{array}$ & .160 & .087 & -.146 & .095 & .083 & .026 & -.027 & .014 & .105 & $.203\left(^{*}\right)$ \\
\hline $\begin{array}{l}\text { Increased } \\
\text { Output }\end{array}$ & -.026 & -.161 & -.161 & $.239\left(^{*}\right)$ & -.038 & -.008 & -.150 & -.066 & $.290\left({ }^{\star *}\right)$ & $.306\left(^{* *}\right)$ \\
\hline
\end{tabular}

\section{Summary, Conclusions and Recommendations}

\subsection{Summary}

From the discussions, the following points came out strongly:

I. The technology was rated highly as of major help in solving customer complaints as well as retaining them, in keeping business records, coping with market competition, incorporating innovations and product differentiations, motivation of employees as well as identifying refinancing needs. On business competitiveness, technology was seen as very effective in increasing sales volume, improving product quality as well as increasing production efficiency.

II. For technology adoption forms on the performance of MSEs, there was a consensus that MSEs have an investment in technology in different ways. However, Pearson's correlation matrix showed a fragile correlation index, (very close to zero), implying that technology adoption forms have had minimal effect on the performance of MSEs. This makes the forms not effective in enhancing performance of MSEs, a possible reason why many MSEs fail within their first two years of operations (Nelson, 1986).

\subsection{Conclusions}

MSEs think they have all the technology they need to manage their businesses. However, they do not realize that these technologies do not get translated into business results. Three possible reasons for this are:

- That what MSEs are using is not appropriate technology

- That if MSEs are using appropriate technology, then the adoption methods are inappropriate

- That MSEs are not empowered (do not have basic capacity) to adopt the technology, to assimilate the technology, to manage it and to control results with it (UNIDO, 2004).

These conclusions correspond to the Government of Kenya's assertion that "MSEs have very restricted levels of technology, inappropriate technology and inadequate institutional capacity to support adaptation and absorption of modern technological skills." This creates a vicious circle of poor performance.

Thus, dependent variables are a function of investment in technology. Consequently, these variables affect the performance of MSEs which in turn influences the type of investment in technology that the MSE adopts. At start-ups 
and early stages of business growth, MSEs have minimal funds to invest in technology which results in inappropriate technology adoption forms and consequently to ineffective MSE performance. This is the situation in Kenya today and unless interventions are made to break this status quo, the MSEs are off the road to achievement of Kenya's vision 2030.

\subsubsection{The MSE Technology Adoption Model}

The above conclusions may be summed up in the form of an MSE technology adoption model which shows that independent variables are a function of investment in technology. Consequently, these independent variables affect the performance of MSE which in turn influences the type of investment in technology that the MSE adopts. As youths start their own enterprises, they have very little capital, little business experience and have not established many business networks. They will therefore not be performing well and will invest mainly in training and purchase of the few pieces of equipment that they need. This minimal investment in technology will result in inadequate and inappropriate technology adoption forms, and consequently to ineffective MSE performance. This vicious circle of poor performance may, however, be broken at any level through some intervention measures. As the MSE breaks this vicious circle of poor performance and moves to the next level of performance, they will have more resources and business networks and will recognize the need to invest more in various types of technology. This will result in better technology adoption forms and consequently to improvement in their MSE performance. The MSE will, therefore, generate more resources to invest more in technology. This process goes on and on and thus becomes cyclic. The variables may be explained as follows:

\subsubsection{Investment in Technology}

Youth-led MSEs investment in technology occurs in any of the following four major forms; Training, Purchase of equipment, Franchising or Subcontracting. The study showed that training was the major form of investment in technology, followed closely by the purchase of equipment while franchising and subcontracting were minimally adopted. The major extraneous variable which influenced the type of investment in technology as discovered from the study was high costs of investments involved and the general illiteracy amongst most youth.

Highly performing MSEs are expected to have accumulated enough resources, networks and knowledge to be able to franchise, subcontract or purchase technology in the form of equipment. However, most of youth-led MSEs (respondents) were young in business, poorly performing and not well established and thus did only invest in training and purchase of equipment.

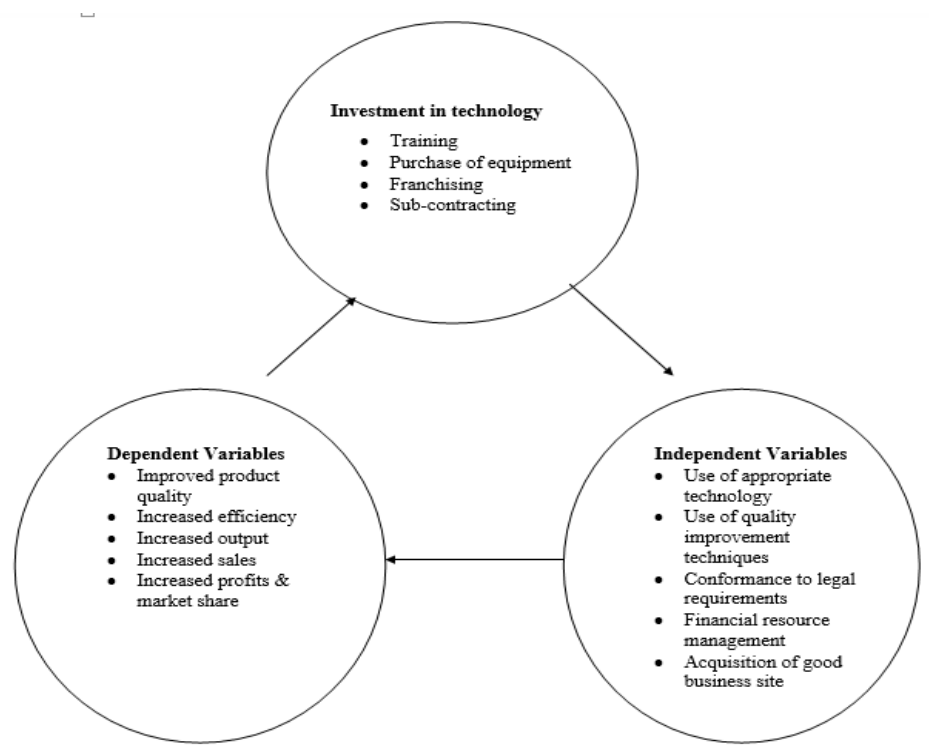

Figure 4: MSE Technology Adoption Model

\subsubsection{Forms of Technology Adoption (Independent Variable)}

The study conceptualized that technology adoption would form independent variables and that their effects were expected to impact positively on the performance of MSEs. This technology adoption took the following forms; use of appropriate technology, effective use of quality improvement techniques, conformance to legal requirements, financial resources management and ability to secure appropriate physical location for business. The study found out that most MSEs adopted all the five forms and they, in turn, affected their businesses positively and in various ways. Their impacts were however hindered by extraneous variables which were mainly in the form of high costs involved and illiteracy amongst most 
respondents. Intervening variable expected to facilitate technology adoption was the availability of information communication technology equipment which the study revealed was not much accessible to youth since most of them feared technology and were also not financially able to acquire the equipment.

\subsubsection{Effects of Technology Adoption on MSES Performance (Dependent Variable)}

From the study, it was discovered that technology adoption had the following results on MSEs; there was improvement of product and service quality, improved efficiency, increased output and sales volume, and increased profitability and market share amongst MSEs. These profits were then re-invested in technology and depending on the amount, did influence the type of investment in technology; thus forming the cyclic model as shown below.

\subsection{Recommendations}

To make MSEs be able to benefit more from appropriate technology and be able to enforce quality practices in their enterprises, deliberate action is necessary from the government to inject more capital to finance all the four forms of investments in technology and assist them to break the vicious circle of poor performance. Once this is done, it is projected that the resulting technology will be able to help MSES achieve improvement of product and service quality, increased efficiency, increased output and sales volume, and increased profitability and market share. These profits would then be re-invested in technology to further enhance the enterprises' sustainability and global competitiveness; thus help Kenya to achieve its vision 2030.

\section{References}

- Ablu M (1997)"Technological learning and innovating in industrial clusters in the south" science policy unit, electronic working paper No. 7 Brighton: University of Sus sex.

- Awe; B. and Tan, H. (1995). "Training Technology and Firm-Level Productivity in Taiwan (China)." Conference on Enterprise and Training Strategies and Productivity. World Bank, June 1995

- Biggs, T. et al. (1995) Technological capability and learning in African enterprises, technical paper no. 288, Washington DC, World Bank.

- Enos, J. (1992). The creation of technological capabilities in Developing Countries, London: Pinter.

- Gall and Borg (1989) Educational Research, an introduction (5thEd) New York and London, Longman.

- Gichira R. (1999).Policies, Strategies and Programmes for Enhancing the Participation of Small and Medium Enterprises in E-Trade. Paper Prepared for Ntfecom's Strategic Workshop Held at Safari Park Hotel, 20th April, 2002

- Government of Kenyam (1989) Strategy for small enterprise development in Kenya towards the year 2000 Government Printers, Nairobi.

- Government of Kenya (1996) Sessional paper No. 2 of 1996 on Industrial Transformation to the year 2020.Government Printers, Nairobi

- Government of Kenya (2004) (22 Jan. 2004) Draft Sessional Paper on Development of Micro and small enterprises for wealth and employment creation for poverty reduction. Government Printers, Nairobi

- Ikiara M.and Okotcho (2005) services trade-related development strategies in tourism,

- ILO (1986) the promotion of small and medium-sized enterprises ILO, Geneva.

- Moyi E and Njiraini p (2005) Towards Technology models for MSES in Kenya: common principles and best practices Kippra Discussion paper NO. 51. Bulletin.

- Ngahu, C. (1995)choice of technology in a small-scale enterprise: international development research center (IDRC)

- Oakland, J. S. (1999) Total organizational excellence -Achieving word class performance, Butterworth Heinemann in Oxford.

- UNIDO (2004) Integrated institutional capacity building services and programmer for technology centers and parks venna: United Nations industrial development organization

- Van Dijki (2001) Innovation and micro and small enterprise development in developing countries: linking knowledge as skills to produce employment: University of Erasmus Netherlands.

- Willimack D. K. et al (2002) Understanding unit and item nonresponse in business surveys, New York, Wiley Inter-Science 